This is an electronic reprint of the original article. This reprint may differ from the original in pagination and typographic detail.

Author(s): Rantamäki, Niina

Title: Co-Production in the Context of Finnish Social Services and Health Care: A Challenge and a Possibility for a New Kind of Democracy

Year: $\quad 2017$

Version:

Please cite the original version:

Rantamäki, N. (2017). Co-Production in the Context of Finnish Social Services and Health Care: A Challenge and a Possibility for a New Kind of Democracy. Voluntas, 28(1), 248-264. https://doi.org/10.1007/s11266-016-9785-1

All material supplied via JYX is protected by copyright and other intellectual property rights, and duplication or sale of all or part of any of the repository collections is not permitted, except that material may be duplicated by you for your research use or educational purposes in electronic or print form. You must obtain permission for any other use. Electronic or print copies may not be offered, whether for sale or otherwise to anyone who is not an authorised user. 


\title{
Co-production in the context of Finnish social services and health care - a challenge and a possibility for a new kind of democracy
}

\begin{abstract}
Alongside the ongoing renewal process of the Finnish welfare state, the role of the citizens is also revisited. So far the attention has mainly focused on how the responsibility for service provision is shared between the public sector and the service users, while the role of public services as a part of the democratic system has been more or less ignored. Based on the results from a 3-year participatory action research project called KAMPA, this article will discuss if the development of co-production in the context of public welfare services shows the way forward toward a new kind of society where democracy is an inseparable part of the structures and procedures of the service provision. The data gathered during the project (textual material, interviews, notes from meetings, and observation diaries) is analyzed using thematic analysis. The results show that while legislation and official policies strongly highlight the participation of citizens and service users there are still many obstacles to overcome at both the attitudinal and practical level. The development of coproduction and arenas of a new kind of democracy requires continuity in the attempts and recognition of the achievements, but it also has the potential to demonstrate the way in which a new more lively democratic society can come true in practice.
\end{abstract}

\section{Keywords}

Co-production, Democracy, Social services and health care, Participatory action research 


\section{Introduction}

The central role played by public service agents and professionals has been characteristic of the Finnish welfare state that is based on the social democratic welfare model (Esping-Andresen 1990, pp. 26-27). During the period of a strong welfare state until the end of the 1980s, public services were seen as being a favor made by the public authorities and social- and healthcare professionals to the citizens who, in their turn, controlled service through the democratic system. Knowledge generated by professional education was perceived as a guarantee of service user -oriented operation while local self-government, based on representative democracy, ensured local residents the opportunity to participate in and influence the local authority's activities and thus also public welfare services. (Evers 2006; Niemi-Iilahti 2003, p. 280).

Since the beginning of the 1990s, demands for service users to take responsibility and play a more active role in the private and third sectors in the provision of welfare services has become stronger (Julkunen 2001). Different, and partly contrary, causes can be identified behind the interest, which according to Esping-Andersen (1996, pp. 6-7) may be divided into two categories: challenges characteristic of the welfare state itself, and the challenges provoked by external forces. The former is related to discussions concerning the functionality of the public welfare services and their capability to meet the increasingly individualized needs of people. While some argue that the welfare state itself is a cause of the never-ending growth of the needs, others consider the biggest problem to be the alienation of services from the real life of the people; the escaping behind professional discourses and the hierarchy of the service structures. (Pestoff and Brandsen 2008, p. 3; Fledderus, Brandsen, and Honingh 2014, p. 425). External causes may be crystallized in a mixture of demographic changes, especially in the rapidly growing number of elderly people and challenges related to public finance. The recession of the early 1990s in Finland had a deep effect on the economy of the country, and together with the arrival of the NPM in the public sector it significantly changed the general sociopolitical atmosphere. Along with the big depression that 
began in 2008, the weakening of the economic basis of the welfare state has reached a position of "a common truth" that cannot be passed.

A solution to the challenges faced by the welfare state has been sought by redefining the distribution of work between the state and the people using the welfare services, with the aim to diminish the role of the public sector and respectively give more responsibility as well as power to the people themselves. Secondly, a significant part of the provision of the public services has been transplanted to the market sector by opening them up to competition with the aim to increase cost efficiency as well as the freedom of choice of the service users. As a consequence of these changes the relationship between the citizen and the state has little by little adopted characteristics that in traditional sectoral thinking are seen as being more typical of the relationship between the consumer and the private service provider (See Pestoff 2012, 14; Julkunen 2006; Möttönen and Niemelä 2005).

However, the discussion about the changing relationship between the state and its citizens in the context of welfare services may not be limited only to them, but it should be also reviewed in connection to a broader discourse related to the devolution of democracy. In Finland - as is the case worldwide - there is growing concern that there is a diminishing amount of people using their right to influence public affairs through representative democracy (see Pestoff 2014, 385). Due to this the government has initiated developing programs to promote citizen participation and the functionality of representative democracy, but in practice the emphasis has been on how to educate people to act in the context of existing democratic structures and procedures. (See Raisio and Vartiainen 2011; Pietikäinen 2010). What has received less attention is that in the context of various societal changes the whole idea of democratic participation should be rethought from time to time. It is important to remember that fundamentally democracy is not only about voting but instead, above all, is a connection between the people and the society they are living in, and that every kind of interaction between the state and the citizen either promotes or prevents the realization of democracy (Matthies 
2008, pp. 66-67; see also Cornwall \& Gaventa 2001). This highlights the role of public services as an arena of democratic citizenship and comes close to what Evers (2010, p. 43) calls civicness - the capacity of public institutions, organizations, and procedures to stimulate, reproduce, and cultivate civility.

My interest in this article is directed toward the question of whether the development of coproduction in the context of public welfare services shows a way to a new kind of society where democracy is an inseparable part of the structures and procedures of service provision. The article is based on a case study carried out alongside the development project called KAMPA (Citizen participation and community orientation in the rural welfare services), which was carried out in a mid-sized Finnish town during 2011-2013. The general goal of the project, financed by The Ministry of Social Affairs and Health, was to strengthen the welfare services in Finnish rural areas by applying models which take citizen participation and community orientation as a starting point. The theoretical background of the development work is based on the idea of co-production, which according to Pestoff (2008) refers to the participation of citizens and their communities in the provision of public services at the different stages of the service process starting from the decision making level and ending at the use of services. I will approach the question of the relationship between the public welfare services and democratic citizenship by reflecting on what the factors are that prevent and contribute to co-production in the context of the Finnish public social services and health care and thus hope to find an answer to the question of whether co-production would open possibilities for a new kind democratic citizenship.

\section{Multifold essence of co-production}

The concept co-production is used to illustrate involvement of clients or end-users in the production of the services and was originally applied to public services by Ostrom and her colleagues in the 1970s at Indiana University. Their interest toward co-production was awakened by the finding that the production of services unlike the production of goods is very rarely possible without the active 
participation of service users. (Pestoff and Brandsen 2008; Pestoff 2012). In the tradition of Ostrom co-production can be defined as: ' ...the mix of activities that both public service agents and citizens contribute to the provision of public services. The former are involved as professionals, or `regular producers, while ‘citizen production’ is based on voluntary efforts by individuals and groups to enhance the quality and/or quantity of the services they use.' (Parks et al. 1981, 1999, ref. Verschuere 2012, p. 1085.)

Later, in different cultural and societal contexts as well as at the different level of analysis, the concept of co-production has taken on various definitions and contents. According to Pestoff (2012, 17-18), the term is used both as a more precise concept that refers to the participation of citizens and the third sector organizations in the delivery of public services and as a general term that encompasses all types of citizen participation in public service provision and at its different levels from policy making to policy implementation. In its broader meaning co-production covers also the dimensions of 'co-management', which is used when referring to collaboration between the public, private, and the third sector organizations in the provision of services, and it covers also 'cogovernance', which stands for third sector organizations and the groups of citizens that take part in the planning and design of public services. (See also Pestoff and Brandsen 2008, p. 5). Basically, co-governance is something that occurs at the organizational level and focuses on policy formulation while co-management and co-production in their narrow meaning are about the implementation of these policies. However, it is important to notice that these different concepts and definitions of co-production are not mutually exclusive, but they also may be combined; for example, TSOs providing services in collaboration with the public sector may also act at the level of policy formulation as well as offer individual service users possibilities to take part in the provision of services. (See also Bovaird 2007; Bovaird and Loeffler 2012).

Brandsen and Honingh (2016), based on the meta-analysis of Ostrom’s and Parks' classic definitions of co-production, for their part have questioned the views that see ‘co-production' as an 
umbrella concept for all the citizen participation in the field of public services. They point out that neither Ostrom nor Parks includes interorganizational collaboration in their definitions, but instead they focus on participation between public agencies and individuals or groups of citizens that are personally using the services. They also separate the direct contribution of service users during the service design or production process from overall participation in the design and delivery of services including advocacy or inputs occurring outside an organizational context or activity. With the latter, they for example refer to different kinds of representative councils that in practice do not have a direct connection to the service production.

It is clear that co-production covers many kinds of relationships between the professional service providers and the citizens or service users as well as a mix of activities that take place at the different stages of service design and the delivery process. However, as Verschuere et al. (2012, p. 1085) assert, the basic idea of co-production in the context of the public welfare services should not be limited to the examination of the roles or actions of different stakeholders, but rather it should be understood as a co-operative relationship characterized by shared goals and aims. In this regard an inseparable part of co-production is the shared interest to contribute in the process that is seen as being worthwhile both from the perspective of citizens and professionals and which makes it possible to reach outcomes that otherwise are maybe unobtainable or even invisible. In a similar vein Bovaird and Löffler (2012, 42; see also Sancino 2016, 415 - 419) note that co-production may produce either private value alone or public value alone - but at its best, it creates both. While the primary goal of co-production is to improve the quality and functionality of the services which aim to add user value and value to wider groups who are indirectly affected by the services, the process of co-production also includes huge possibilities to strengthen social cohesion, to support democratic processes as well as to ensure environmental sustainability of all policies.

Sancino (2016, p. 413-415), referring to the richness of different views on the definition of coproduction, suggests that every actor in the field of co-production should make clear his starting 
points and take a position on the conception of co-production he uses. As Ewert and Evers (2014, p. 427) state, the impacts and implications of co-production for service provision and citizen participation may differ a lot depending on through which kind of lens it is observed. The importance of this becomes very clear when reviewing how well the idea of co-production fits with the different political models. From the neoliberal perspective, emphasis on co-production has served the efforts to decrease the dependency of citizens on the state and to support them to help each other. Instead, from the communitarian perspective that is the starting point here, the relevance of co-production is interlocked with its possibility to tighten the bonds that join together the citizens and the state (see e.g. Johansson and Hvinden 2007; Evers 2006 and 2010; Pestoff 2008).

According to Verschuere et al. (2012, pp. 1086-1093), the research of co-production has mainly been descriptive. Based on a literature review, they have identified three broad research lines related to co-production. These are the motivations behind co-production, the effective organization of coproduction, and the effects of co-production. The question of motivation involves both citizens and their organizations as well as the public organizations and professionals working in these and also the circumstances facilitating or inhibiting co-production. Secondly, research concerning coproduction has dealt with the question of under what kind of conditions effective co-production is possible. In addition to being able to understand the needs of the clients, the results of the research underline the importance to understand an organization's own expectations and to find a way to reach these. The third research theme dealing with the effects of co-production provides some evidence that co-production can improve the quality of the services from the perspective of the service users. However, there are still many questions left unanswered; especially the connections between co-production and democracy as well as co-production and accountability are problematic.

\section{The research and development process}

I will next look at the question of whether the development of co-production in the context of public services can show a way toward a new kind of democratic citizenship. I aim to achieve this by 
analyzing the challenges and possibilities related to the development of co-production at the levels of service governance and service provision in public social and health services.

The article is based on the experiences of a research and development project called KAMPA, which took place at the unit of municipal social and health services of a Finnish town (The Town) with 48000 inhabitants. The incentive for the project was the understanding that both the renewal process of the welfare state and the discourses concerning the democratic development of society have focused on setting the dividing line between public and private responsibility rather than on trying to find new ways to combine resources when facing the shared emerging challenges of democracy and services.

The project followed the principles of participatory action research (PAR). Accordingly, in addition to observing and analyzing the factors related to the development of co-production, the project also aimed to raise the awareness of the citizens and public authorities concerning the possibilities included in co-production both from the perspective of improving service quality, effectiveness, and service outcome and the creation of a new kind of democratic citizenship (see Winter and MunnGiddings 2001; McNiff and Whitehead 2009). This is what Healy (2001, p. 96) describes as the triple meaning of PAR: to produce knowledge, to raise awareness, and to educate.

The researcher worked in close co-operation with the local developer of the KAMPA-project, and the central stakeholders of the project included service-users and professionals working for the town's social services and healthcare at the levels of administration or service provision throughout the whole development and research process. The project began by mapping the current situation with the aim to find out what the possibilities are for citizens and service users to influence the design and implementation of services and how these are tapped. On the basis of the mapping phase, two concrete development goals were selected. The first, located at the level of cogovernance, was to create possibilities for regular interaction concerning the design of the services 
in general between the citizens and those in a decision-making position in the social services and health care and the second, more focused on the level of co-production, was to create an arena for the employees and service users to work together to improve the quality and functionality of the services. The project then continued by implementing these into practice. A more detailed overview of the research and development process as well as the data sources are described in Figure 1.

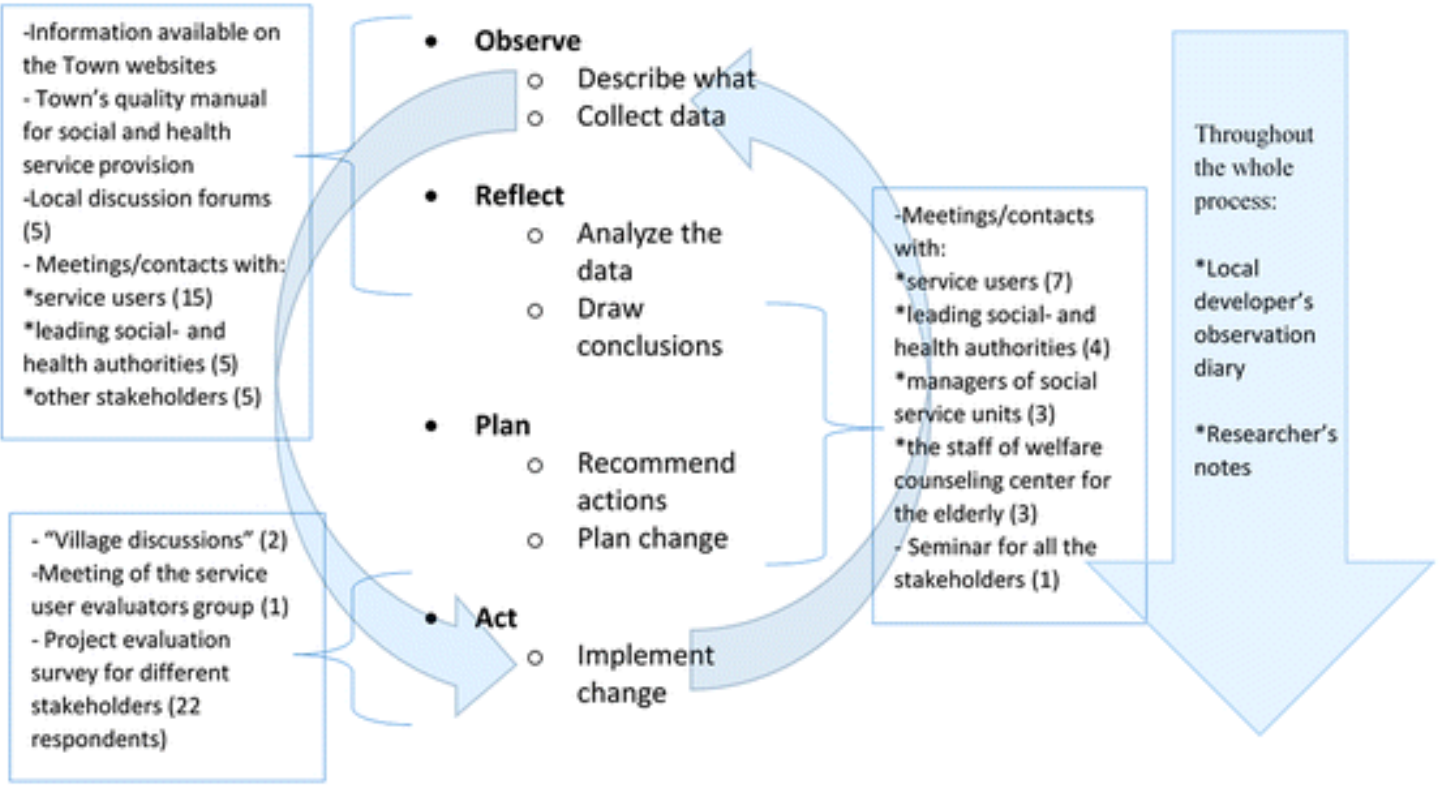

Figure 1. The development and research process of the KAMPA-project based on Working PAR model (Wadsworth 1984, p. 44).

The main data sources during the process were the observation diary of the local developer and the notes of the researcher where they wrote down their findings related to the development of coproduction. In addition to these, the information available in the Town's quality manual for social and health service provision and on the Town's website, memos from local discussion forums and meetings with different stakeholders of the project along with the results of the project evaluation survey were exploited.

Based on the cyclic structure of PAR data collection and analysis they were partly overlapping. The data were organized and analyzed using inductive thematic analysis (e.g. Ayres 2008). In the first 
phase of the analysis process the written material was read through several times, and both implicit and explicit ideas related to the development of co-production were coded with different colors. The reading was guided by very broad and practical questions like the following: What is already done? Why is this done? How is this working? What could or should be done in the future? Next the coded data were moved into an excel table and divided into subcategories that were generated based on the understanding formed during the first phase. The original source of each of the data units was indicated (i.e. the situation and the date). In the case of direct quotations written down by the local developer in her observation diary and by the researcher in her notebook, the information concerning the role of the speaker was also attached.

In the third phase the initial results of the thematic analysis were presented to the stakeholders of project, and they were asked to reflect on the findings from their own perspective. The comments, information, and the ideas received from them were included in the research data. In the last phase of the analysis the tentative categories were grouped under higher order headings, and the understanding concerning the possibilities and challenges related to the new kind of democratic participation in the context of public services was strengthened and deepened.

As a result of the analysis three main themes were identified that describe the factors affecting the development of co-production in the context of public social services and health care. These are principles guiding the service provision, the attitudes, and the practical questions affecting the fulfillment of these principles.

\section{The starting point for the development of co-production: the guiding principles and attitudinal environment}

The principles guiding the operations of public service provision

During the mapping phase it became clear that both national legislation and national and local strategies highlight the role of citizens and service users in the field of public activities. According 
to the constitution of Finland (731/1999), every individual has the right to participate in and influence the development of society, and the public authorities shall promote the fulfillment of these rights. The Act on the Status and Rights of Social Welfare Clients (812/2000) as well as the ethical codes guiding the work of the practitioners in the field of social services and health care emphasize the realization of these rights. Also, different quality management programs applied in the field of social and health services strongly support these objectives by highlighting the significance of the clients' rights and feedback given by them as the premises for high-quality service design and delivery.

In addition to municipal democracy, the practices of the Town already offer many concrete ways for the inhabitants and the service users to influence the design of the services and to give feedback concerning them. These can be categorized, according to Evers (2006), as a 'welfarism' type of citizen involvement. Formal channels, like the option to contact a social- or patient ombudsman or to make a written reminder or a complaint, are based on the legislation and follow formal procedures. Informal channels include verbal or literal feedback, entry to allocated client surveys, or contacts with the members of the local municipal board of social services and health care. Inside the organizational structure of the Town, there also exists different service user councils like The Elderly Council and The Disabled Peoples' Council, which act as a representative and advocate of certain groups of citizens in municipal decision-making, but their role is seen as being more consultative than interactive.

Although there already are various channels which allow citizens and service users to give feedback and to take part in the development of services based on the results of the study, these are quite poorly exploited. People told that they felt themselves to be uninformed about the existing possibilities and unsure how they work: 
The problem is that people don't get enough information. Especially if one doesn't have an internet connection or doesn't use e-mail. So how can you influence anything if you don’t have any knowledge? (Participant in a village meeting)

Others see the problem of being more about the lack of two-way interaction:

How do you know whether the feedback given has had any kind of influence? We need feedback from the feedback. (Participant in a meeting of service users)

Within service provision there are also certain challenges related to the piggybacking of the information received through different channels:

We know a lot of what is not working but only a little bit of what is working. Or at least the feedback concerning the good experiences doesn’t get around as widely as bad experiences. (Participant in a meeting with the leading social and health authorities)

The procedures guiding the processing of the information received through the formal feedback channels are outlined by the legislation, but the common plan concerning the exploitation of the feedback gathered via informal channels is missing. This means that the information received from the service users tells much more about what people are dissatisfied with than what they are satisfied with. What is most worrying from the perspective of co-production and the democratic citizenship is that the two-way interaction that creates the relationship between the citizens and the public services in practice is almost non-existent.

\section{Attitudinal environment}

Although at the principled level the preparedness and preconditions for the new kind of working culture are remarkably good, and the need to develop current procedures is recognized, in practice many obstacles exist. There emerged, among the service users and the local authorities, certain 
prejudices and doubts concerning the advantages of a more active participation of the service users in the field of service design and development. Especially the older people are used to acting inside the operational culture where professional expertise is highly valued and seen as overriding in comparison with the experience-based knowledge:

There are many people who think that they don't have enough knowledge to be able to give feedback or they are too old or something. Although in many situations they in fact are the best experts. (Participant in a meeting with service users)

Like the service users, those working on the administrative level made clear their own suspicions. To them the experience-based knowledge of service users and citizens exemplifies subjective thinking, whereas professional knowledge is seen as objective know-how:

How can you make sure that people are not just pushing their own interest? The views of different people may be conflicting and then what to do? (Participant in a meeting with the managers of the social services)

The ones working in the decision making positions also highlighted the limits that are set by the national legislation and municipal economy. To their thinking the greater active participation of the citizens is directly connected to growing demands and not that the people have the competence to understand 'the larger picture':

Money and legislation set their own borders - the feedback from the service users does not change this. (Participant in a meeting with the managers of the social services)

Like these quotations show, in addition to the development of the concrete methods applying the principles of co-production, there is a need to work at the attitudinal level both among the professionals as well as the service users. 


\section{Implementation of the plan: practical challenges and flashes of success}

\section{Village discussions}

With the aim to promote regular interaction between the citizens and the local authorities at the level of governance of the welfare services, the decision was made to organize meetings similar to the local discussion forums organized during the mapping phase of the KAMPA project in the different living areas of the Town. Based on the principles of deliberative democracy, the original idea was to organize a kind of "round table meeting”. There, different issues and ideas connected to the welfare of the residents in the neighborhood could be raised, and the ideas concerning the organization of social services and health care in the future could be outlined together. (See e.g. Fung 2007.)

During the action phase, two local discussion forums named "Village discussion" were organized. While organizing the forums many practical questions and difficulties arose: Who should take the main responsibility for organizing the meetings? How best to find a convenient date and place? What kinds of issues are suitable for discussion? What are the roles of different participants? What is the role of "Village discussions" compared to representative democracy? The initial idea was that the local authorities would organize the meetings in co-operation with the residents of the neighborhood, but in practice this turned out to be far too complicated. The difficulties were connected to attitudinal challenges and reflect also the differences between the working cultures of the authorities, for whom the meetings were part of their duties, and of the volunteers, who took part by their own choice.

The practical implications of "Village discussions" were different in various living settings. The first meeting, which was organized in a school building of a municipality to whom the Town provides social services and healthcare, turned out to be a kind of "question hour" where policymakers, sitting behind a table, answered questions set by the audience of local residents. The other 
meeting, which took place in a community house of a small village, was more relaxed and gave the impression of dialogical communication. The differences related to the atmosphere of the meetings seemed to be dependent on the concrete form of how seats and tables were arranged in the room, the personal characteristics of the chairperson, and the existing tensions between different stakeholders - basically things that are characteristic of interaction between different people and groups (see e.g. Raisio and Vartiainen 2011).

The discussions at the meetings dealt mainly with the issues related to the services provided by the municipality. People were keen to know about the future plans regarding the neighborhood services available at the moment near them and asked questions related to their own situation. Local authorities answered the questions posed and told in general about their current plans. Afterwards, both the local authorities and the villagers said that they were satisfied with the meetings though their views differed from each other. For the local authorities the village meetings appeared like an exam that they had to pass. A manager in the field of social services summed this up by saying maybe jokingly: “We pulled through quite well, didn’t we?” For the villagers the meetings gave an opportunity to have an insight into the system that takes care of the services:

It’s good that we know now how the people making decisions concerning our social services and health care look like. (Participant of a village meeting)

However, some of the participants also pointed out that the common discussion changed the way they see the services now:

Now that we have discussed about the services, I pay attention to different things. I feel that my perspective is now much wider than it used to be, and I think about things differently. (Participant of a village meeting) 
Service-users as evaluators -groups

The development of service-users as evaluators -group is based on the idea of client-expertise. According to Beresford (2010, p. 497), the kind of partnership between the service users and service providers represents consultative involvement; although service users give their own experiences and knowledge in the use of the service provider, the final decision concerning the elements that are exploited is made by the professionals working inside the system. This kind of co-production is very common in the private sector where the experience and knowledge of end-users is seen to be useful in the effort to develop products or services that are more tempting; with the result hopefully being a competitive advantage for a company (Voorberg, Bekkers, and Tummers 2015, p. 1334). However, in the context of the public sector the beneficiaries are either the ones that took part in the group or at the very least their peer citizens.

The development of the "Service-users as evaluators" groups faced its first challenge when looking for a service unit that would be willing to act as a pilot agency. The reluctance of the service units toward taking this step was mostly justified by the lack of time:

Where to get resources for the work that is not obligatory according to law? Although it is very important. (Participant in a meeting with the mangers of social service units).

Some were also of the opinion that the input of service users does not actually provide any extra knowledge on top of the professional knowledge:

Whose participation is needed? And why? What would be its contribution? What is the added value it will provide? (Participant in a meeting with the managers of social service units)

After a few negotiations inside the Town's social- and health care department the welfare counseling clinic for the elderly that operates on a low-threshold principle promised to act as a pilot. 
The clinic chose the preventive physical check-ups that are allocated to those clients of 67 or 74 years of age as the service area to start. The next challenge that emerged was how to reach the service users that have already taken part in the check- ups without breaking the law that regulates the use of the personal data of social- and health service users. Due to the legislation, invitations could not be given to those who actually received the examinations, but instead they were sent to randomly selected preventatives of the whole age group.

In all, 4 of the 30 addressees expressed their willingness to take part in the meeting of "serviceusers as evaluators”-group. However, in the end, only two of them took part in the meeting. Although the number of participants was a disappointment, both the service-users and the members of staff were very pleased with the event. The discussion around the coffee table dealt with the experiences of service users concerning the preventive physical check-ups as well as general issues related to the current and the future action of the counseling clinic. In order to achieve better synergy benefits, the Town had made a plan to move the clinic from the town center closer to the health center that is located a few kilometres outside the town center. From the perspective of service users, this plan however included many disadvantages which were also discussed. At the group meeting there was also present the manager of the welfare clinic services, which the service users appreciated. But it was considered as being particularly important by the staff of the clinic who felt that they far too rarely have an opportunity to discuss the issues related to the development of their own unit with their manager.

The case of "service users as evaluators - group" showed that although the initial focus of certain co-productive activities might be quite narrow, which was here to evaluate and develop the functionality of a certain service, during the common conversation there may arise issues that have much broader dimensions, like what is the best location for the welfare counseling clinic for the elderly. In addition, from the perspective of the research the meeting revealed that the challenges related to the development of co-productive working methods are at least partly due to the 
organizational culture and procedures where the employees themselves are missing the possibility to participate in the discussions and influence the decisions concerning their own work.

\section{The outcomes of KAMPA development}

Since the KAMPA-project, “Village discussions” have continued and nowadays they are organized regularly 2-3 times a year in different parts of the Town, but their character is still more like a "press briefing” than a co-operation meeting. Instead, the "Service users as evaluators” -group activity ceased to continue.

Among the citizens involved in the project there is disappointment in regard to the results achieved, as the following response in the project evaluation survey shows:

It seemed that during the development process the perspective of the citizens became increasingly narrower. It almost looked like ‘the municipal system’ swallowed the whole idea. (A member of a civic organisation)

However, according to the feedback given by the local authorities at the end of the KAMPAproject, the efforts to develop co-production as a whole have influenced the working culture and working operations of the social services provided by the Town:

It seems that during the project only a few concrete changes have happened. However, a big achievement is that the discussion concerning the importance to hear the voices of our clients has taken much more space alongside the development of these models. But of course, we are still quite far away from talking about the participation of the citizens in a wider perspective. (A leading social and health official)

It is true that the initial results of the KAMPA-project are not that revolutionary. The outcome of the project is much more like the kind of consultative co-operation between the social- and health authorities and the professionals and the inhabitants of the municipality and the service-users than it 
is to co-production or co-governance that refers to real input and influence in the development of the services (see Pestoff 2006, 516). But, referring to the comment of a municipal official above, to change the established action policy of an organization does not take place instantly. However, every endeavor has its own significance, and at least some steps toward a more participative approach inside the public service system have been taken.

\section{What prevents and what contributes to co-production: Chances of democracy}

The goal of this article was to find out whether the development of co-production in the context of public welfare services of Finland could show a way toward a new kind of participative democracy. Like the experiences of the KAMPA-project demonstrate, there are plenty of practical and more attitudinal obstacles to overcome. In fact, it seems that efforts to develop co-productive methods based on the principles of deliberative democracy inside the public service system might be even more challenging than developing co-management that takes place at the organizational level; like in the case where third sector organizations take part in service provision in partnership with the public sector. The kind of co-production the latter case represents fits much better with a managerialistic ideology where the organization and provision of services are divided as separate functions and thus also distanced from the democratic structures of society.

Although the legislation as well as the official debates and strategies place a strong emphasis on citizen participation and democracy, it seems that the effectiveness thinking adopted from the market sector stresses more the functionality of service delivery processes, economic efficiency, and the realization of consumer rights. The discourses are not totally opposite, but the goals they try to achieve differ from each other and especially in regard to the means they use while reaching these goals. This confusion due to contradictory expectations and demands is visible through all the levels of social policy implementation, but it also affects the level of policy formulation. In this regard the turn toward more participatory approaches requires a shift from the oversimplified 
efficiency thinking to a more comprehensive understanding about the factors affecting and creating the wellbeing of the people as well as the elements society is built on. (e.g. Salonen 2014; Helne and Hirvilammi 2015).

Due to the centralization of municipal administration and the renewal of service structures people are worried about the future of public welfare services, and at least partly due to this they also are willing to contribute to public affairs and to develop new participatory approaches both at the level of governance and in the direct provision of welfare services. However, these expectations are not fully met by the municipal authorities and the professionals in the field of social services and health care, who for their part are trying to pull through the day-by-day challenges in the turbulent environment of continuous changes and increasing scarcity. It even seems that in addition to developing co-production with the view to increase citizen participation, also the possibilities of the social and health professionals to influence their own work should be revisited. Like Pestoff (2006, 516) has emphasized, there is a need to both: to find a way so that various stakeholders can make a contribution to better quality of services through dialogue and co-operation with each other and to find a way to motivate and involve them. That is also the basic idea of deliberative democracy; to communicate and understand different points of view and to create the solution together (e.g. Gastil \& Levine 2005).

As mentioned previously, during the KAMPA process only the very initial steps were taken toward the co-production in the context of public services, and it looks like there is still a long way to go before its whole potential, including the democracy aspect, is exploited. As in other cases, when pursuing big changes virtue of patience is needed. The development of co-production and arenas of new kinds for democracy require continuity in the attempts and recognition of the achievements: the more often 'co-production' is mentioned as one possible approach, the more often both the actors inside the service system and the citizens using services begin to consider issues from this perspective - and the same goes for understanding the interfaces between the public services and 
democratic participation. Like Barker (2010, p. 857) has stated, once the citizens and the service users become engaged in co-production alongside the professional producers, there are many possibilities for positive returns. Co-production may even offer the only realistic hope for the survival of social- and health services. But, it also has the potential to demonstrate the way in which a new more sustainable society in terms of economic, social, and ecological dimensions can be created in practice.

\section{Acknowledgments}

I would like to thank the Rural Policy Committee in Finland for financing the research project and the anonymous reviewers for their valuable comments and suggestions to improve the quality of the paper. 


\section{References}

Ayres, L. (2008). Thematic coding and analysis. In L. Given (Ed.), The sage encyclopedia of qualitative research methods. Thousand Oaks: SAGE Publications Inc

Barker, A. (2010). Co-production of Local Public Services. In Co-production a series of commissioned reports (pp. 1-8). LARCI, Baltimore: Local Authorities \& Research Councils' Initiative.

Beresford, P. (2010). Public partnerships, governance and user involvement: A service users perspective. International Journal of Consumer Studies, 34(5), 495-502.

Bovaird, T. (2007). Beyond engagement and participation: User and community co-production of public services. Public Administration Review, September | October 2007, 846-860.

Bovaird, T., and Löffler, E. (2012) From engagement to co-production. How users and communities contribute to public services. In V. Pestoff, T. Brandsen, and B. Verschuere (eds.), New Public Governance, the Third Sector and Co-Production, London: Routledge.

Brandsen, T., \& Honingh, M. (2016). Distinguishing different types of coproduction: A conceptual analysis based on the classical definitions. Public Admin Review, 76, 427-435.

Cornwall, A., \& Gaventa. J. (2001). From users and choosers to makes and shapers: repositioning participation in social policy. IDS Working paper 127, Brighton: Institute of Development Studies.

Esping-Andersen, G. (1990). The three worlds of welfare capitalism. Princeton, NJ: Princeton University Press.

Esping-Andersen, G. (1996). After the Golden Age? Welfare state dilemmas in a global economy. In G. Esping-Andersen (Ed.), Welfare States in Transition: National adaptations in global economies. London: SAGE Publication Ltd.

Evers, A. (2006). Complementary and conflicting: The different meaning of 'user involvement' in social services. In A-L. Matthies (ed.), Nordic Civic Society Organizations and the Future of Welfare Services: A model for Europe? Nordic Council of Ministers, Copenhagen:

TemaNord.

Evers, A. (2010). Civicness, civility and their meanings for social services. In T. Brandsen, P. Dekker, \& A. Evers (Eds.), Civicness in the governance and delivery of social services.

Germany: Nomos Verlagsgesellschaft, Baden-Baden.

Ewert, B. and Evers, A. (2014). An ambiguous concept: On the meanings of co-production for health care users and user organizations? Voluntas, 25(2), 425-442.

Fledderus, J., Brandsen, T., \& Honingh, M. (2014). Restoring trust through the co-production of public services: A theoretical elaboration. Public Management Review, 16(3), 424-433. 
Fung, A. (2007). Minipublics: Deliberative design and their consequences. In S. W. Rosenberg (ed.), Deliberation, Participation and Democracy. Can the People Govern?, Houndmills: Palgrave Macmillan.

Gastil, J., \& Levine, P. (Eds.). (2005). The deliberative democracy handbook. Jossey-Bass, San Fransisco: Strategies for Effective Civic Engagement in the Twenty-First Century.

Healy, K. (2001). Participatory action research and social work: A critical appraisal. International Social Work, 44 (1), 93-105.

Helne, T., \& Hirvilammi, T. (2015). Wellbeing and sustainability: A relational approach. Sustainable Development, 23, 167-175.

Johansson, H., \& Hvinden, B. (2007). What do we mean by active citizenship? In B. Hvinden \& H. Johansson (Eds.), Citizenship in nordic welfare states: Dynamics of choice. London: Duties and Participation in a Changing Europe, Routledge.

Julkunen, R. (2001). Change of direction: Political reform of the 1990s in Finland. Tampere: Vastapaino.

Julkunen, R. (2006). Who is responsible? The limits of the welfare state and public responsibility. National Research and Development Centre for Welfare and Health-Stakes, Helsinki.

Matthies, A.-L. (2008). Citizen participation and community-orientation in the turning point of European welfare policy. In I. Roivainen, M. Nylund, R. Korkiamäki, \& S. Raitakari (Eds.), Communities and Social Work: In the Errand of Citizen or Client?. Jyväskylä: PS-Publishing.

McNiff, J., \& Whitehead, J. (2009). Doing and writing action research. London: SAGE Publication Ltd.

Möttönen, S., \& Niemelä, J. (2005). The Public and the Third Sector: New forms of cooperation. Jyväskylä: PS-Publishing.

Niemi-Iilahti, A. (2003). Citizen empowerment: A challenge for local democracy in Finland. Kunnallistieteellinen aikakausikirja 31(4), 279-289.

Parks, R. B., Baker, P. C., Kiser, L., Oakerson, R., Ostrom, E., Ostrom, V., Percy, S. L., Vandivoret, M. B.,Whitaker, G. P., and Wilson, R. (1981). Consumers as co-producers of public services: Some economic and institutional considerations. Policy Studies Journal, 9(7), 10011011.

Pestoff, V. (2006). Citizens and co-production of welfare services. Public Management Review, 8(4), 503-519.

Pestoff, V. (2008). A democratic architecture for the welfare state: Promoting citizen participation, the Third Sector and Co-production. London and New York: Routledge. 
Pestoff, V. (2012). Co-production and third sector social services in Europe. Some crucial conceptual issues. In V. Pestoff, T. Brandsen, \& B. Verschuere (Eds.), New Public Governance, the Third Sector and Co-Production. London: Routledge.

Pestoff, V. (2014). Collective action and the sustainability of co-production. Public Management Review, 16 (3), 383-401.

Pestoff, V., \& Brandsen, T. (2008). Co-production: The Third Sector and the delivery of Public Services. London: Routledge.

Pietikäinen, P. (Ed.). (2010). Power in Finland. Helsinki: Gaudeamus.

Raisio, H., \& Vartiainen, P. (Eds.). (2011). From an Illusion of participation to genuine citizen influence: About deliberative democracy and implementation of citizens' juries in Finland. Helsinki: University of Vaasa and Association of Finnish Local and Regional Authorities.

Salonen, A. (2014). Ecosocial welfare paradigm: New direction for societal thinking and action on filling Earth. Social Pedagogical Journal, 15, 31-62.

Sancino, A. (2016). The meta co-production of community outcomes: Towards a citizens' capabilities approach. Voluntas, 27, 409-424.

The Act on the Status and Rights of Social Welfare Clients 812/2000. Retrieved June 14, 2015, from http://www.finlex.fi/fi/laki/ajantasa/2000/20000812.

The Constitution of Finland 731/1999. Retrieved June 14, 2015, from http://www.finlex.fi/fi/laki/kaannokset/1999/en19990731.pdf.

Verschuere, B., Brandsen, T., \& Pestoff, V. (2012). Co-production: The state of the art in research and the future agenda. Voluntas, 23, 1083-1101.

Voorberg, W. H., Bekkers, V. J. J. M., \& Tummers, L. G. (2015). A systematic review of cocreation and co-production: Embarking on the social innovation journey. Public Management Review, 17(9), 1333-1357.

Wadsworth, Y. (1984). Do it yourself social research. Melbourne: Victorian Council of Social Service and Melbourne Family Care Organisation.

Winter, R., \& Munn-Giddings, C. (2001). A handbook for action research in health and social care. London and New York: Routhledge. 